\title{
Lost Classroom, Lost Community: Catholic Schools' Importance in Urban America by Margaret F. Brinig and Nicole Stelle Garnett. Chicago: University of Chicago Press, 2014. 202 pp., $\$ 48.00$.
}

Ann Marie Ryan

Loyola University Chicago, aryan3@luc.edu

Follow this and additional works at: https://ecommons.luc.edu/education_facpubs

Part of the Catholic Studies Commons, and the Education Commons

\section{Recommended Citation}

Ryan, Ann Marie. Lost Classroom, Lost Community: Catholic Schools' Importance in Urban America by Margaret F. Brinig and Nicole Stelle Garnett. Chicago: University of Chicago Press, 2014. 202 pp., \$48.00.. American Journal of Education, 125, 1: 141-146, 2018. Retrieved from Loyola eCommons, Education: School of Education Faculty Publications and Other Works, http://dx.doi.org/10.1086/699805

This Book Review is brought to you for free and open access by the Faculty Publications and Other Works by Department at Loyola eCommons. It has been accepted for inclusion in Education: School of Education Faculty Publications and Other Works by an authorized administrator of Loyola eCommons. For more information, please contact ecommons@luc.edu.

\section{(c) (i) $\Theta \Theta$}

This work is licensed under a Creative Commons Attribution-Noncommercial-No Derivative Works 3.0 License. (c) University of Chicago Press 2018 


\section{Book Review}

Lost Classroom, Lost Community: Catholic Schools' Importance in Urban America by Margaret F. Brinig and Nicole Stelle Garnett. Chicago: University of Chicago Press, 2014. 202 pp., \$48.00.

Ann Marie Ryan

Loyola University Chicago

In Lost Classroom, Lost Community: Catholic Schools' Importance in Urban America, Margaret F. Brinig and Nicole Stelle Garnett set out to understand how the precipitous loss of urban Catholic schools over the past several decades has affected the social order and social cohesion of the neighborhoods in which these schools once served as community anchors. Fittingly, they begin their exploration with a history of Catholic schools in the United States, from their fledgling and contested beginnings in the nineteenth century to their height in the mid- to late twentieth century. In this condensed but informative historical account, Brinig and Garnett rightly conclude that much of the development of Catholic schools relied on an unsustainable model of a mission-based American Catholic Church aiming to educate ethnic Europeans in Catholic schools staffed by legions of religious sisters who taught for little to, at times, no salary.

The second chapter delves into the decline of Catholic schools and the growth of charter schools in the late twentieth and early twenty-first centuries. The authors scan the diversity of laws governing charters across states, with special attention to those preventing the integration of religion for fear of violating the Establishment Clause of the US Constitution. However, Brinig and Garnett present several cases in which Catholic dioceses have participated in the conversion of schools into charters. Rather than make them backdoor Catholic schools, Catholic dioceses have been careful to shape these schools with secular values or character programs. These examples seem to be included to exemplify how Catholic leaders are not keen to shift from the traditional Catholic school model just yet.

ANN MARIE RYAN is an associate professor of education in the School of Education at Loyola University Chicago. She researches the history of Catholic schooling in the United States from the early to mid-twentieth century with a focus on the intersections between Catholic schools and public education reforms.

For permission to reuse, please contact journalpermissions@press.uchicago.edu. 
After describing the current educational terrain in which Catholic schools are situated, the authors examine the educational and social concerns that motivated them to investigate the closure of Catholic schools. In response, they construct a series of statistical studies to specifically ask, What does a Catholic school mean to an urban neighborhood? They focus on Chicago, one of the largest Catholic archdioceses in the United States. For comparison purposes, they look at Philadelphia and Los Angeles Catholic schools. They also look at the social impact that charter schools in Chicago have had on their communities.

In their examination, Brinig and Garnett focus on Catholic schools as community institutions rather than educational ones. The authors argue persuasively that Catholic schools generate social capital by building strong neighborhood networks. They also document the dangers that have arisen as Catholic schools close at an alarming rate and are replaced by charter schools and others that do not yet seem to fulfill the same roles and promise as Catholic schools. While these new institutions focus on academic outcomes, Catholic schools are mission driven, focused on the whole child and the common good (Bryk et al. 1993). As a result, Catholic schools are multidimensional and contribute considerably to their neighborhoods, perhaps most importantly by generating social capital. In their study, Brinig and Garnett equate social capital in communities with greater social order and social cohesion.

Chapters 3 and 4 of the book focus on the Archdiocese of Chicago's schools. Brinig and Garnett offer a detailed account of the data analyzed (and its limitations) by examining the effects of school closures on social cohesion and social disorder in neighborhoods in Chicago through regression analyses. In chapter 3, the authors analyze data from the Project on Human Development in Chicago from 1984 to 1994, the 1980 and 1990 censuses, and Catholic school closures in those same Chicago neighborhoods from 1984 to 1994. Brinig and Garnett conclude that school closures increased social disorder and lessened social cohesion. Chapter 4 specifically examines Catholic school closure data from 1990 to 1996 in Chicago against neighborhood crime data from 1999 to 2005. Brinig and Garnett suggest that there may be a link between Catholic school closures and increased crime rates in urban neighborhoods after those closures. The authors are careful not to attribute a causal link between school closures and the rate of decline; rather, they contend that there was something of a "disorder cascade"an increase in social disorder, a decrease in social cohesion, and less collective efficacy. In chapter 5, Brinig and Garnett did not find any connections between charter schools and reduced crime.

Brinig and Garnett shift their focus in chapter 6 to Philadelphia and Los Angeles. Both cities have large and demographically diverse Catholic populations within archdioceses that support a sizable number of Catholic schools. These 
cities also had data sets that allowed the researchers to replicate, to some extent, the studies that they conducted in Chicago. The Philadelphia data set spanned 2005 to 2009, and, when analyzed, the authors' conclusions were similar to those for Chicago. The data from Los Angeles, from 2000 and 2001, did not result in similar findings and differed because very few Catholic schools in the Los Angeles area have closed. There is no direct indication of why there have been fewer closures in Los Angeles; however, Brinig and Garnett explore how the Archdiocese of Los Angeles engaged in a more planned approach to the development of schools compared with the other cities, and this approach may have contributed to the need for fewer closures. The data used for Los Angeles compared neighborhoods with and without Catholic schools as a proxy for those with open and closed Catholic schools. The rationale for this method was that they found open Catholic schools in Chicago were associated with less crime; therefore, they believed it appropriate to assess whether the same phenomenon could be found in Los Angeles.

The authors explain that they believe the difference in findings for Los Angeles is due to overall lower levels of social capital in Los Angeles. This is based on the findings from the Social Capital Community Survey used as part of their larger data set. They offer a rich and compelling discussion about the survey and reasons why the city has a distinctly different social capital profile than Chicago and Philadelphia. Brinig and Garnett conclude that they are unable to make any statements about the impact of Catholic schools on urban Los Angeles neighborhoods.

From the introduction until chapter 3, Brinig and Garnett use social order and cohesion to define social capital. In chapter 3, they shift to Robert Putnam's (2000) parsimonious definition of social capital centered on the notion of mutuality and trustworthiness within social networks. After presenting data on Chicago, Philadelphia, and Los Angeles, the authors offer a more in-depth examination of what social capital is and why it matters in relationship to schools in chapter 7. Although scholars define social capital in various ways, Brinig and Garnett take a more straightforward approach and focus on social capital as "social networks that make urban neighborhoods function smoothly- the connections that draw residents together and enable them to suppress evils like crime and disorder" (113-14).

Key to Brinig and Garnett's definition of social capital is trust between neighbors, trust that lends itself to looking out for one another. They connect this with the literature on education and social capital that has demonstrated how trust between parents and school staff(Coleman, 1988) and trust among all members of a school community develops social capital within Catholic schools in particular (Bryk et al. 1993). Brinig and Garnett argue further that Catholic schools generate social capital beyond the schoolhouse and into the neighborhoods 
where students reside. The authors find that Catholic schools' value for community service, high academic and behavioral expectations for students, and strong institutional presence are some of the factors that generate social capital.

The penultimate chapter of Lost Classroom, Lost Community enters into the history and current debate over school choice and discusses the development of magnet schools to facilitate desegregation (and current intradistrict school choice programs); the shift away from property tax-based funding formulas; the emergence of tuition voucher programs; and, more recently, the passage of tax credit scholarship programs. At the time the book was written, nine states, along with Washington, DC, and Douglas County, Colorado, had scholarship or voucher programs. In 2018, the number of states with such programs had increased to 27 (National Conference of State Legislatures, 2017; EdChoice, 2018). That represents a stunning threefold increase in a very short period of time. The dramatic uptick in legislation supporting school choice in the form of vouchers and tax credit scholarships is worth the attention of scholars to examine the impact these educational policies are having not only in education but, as Brinig and Garnett's research suggests, on neighborhoods and wider communities. These inquiries should be especially mindful of how school choice affects other social indicators.

Brinig and Garnett support school choice and, in this chapter, focus on demonstrating why they believe it is critical to the survival of Catholic schools. The authors cite studies (Wolf 2007; Campbell 2008) to demonstrate how Catholic schools contribute to the public good by supporting common values through teaching civic skills and principles, contrary to critics of school choice who argue that public schools are the only schools able to do so. Brinig and Garnett acknowledge that there are many debates over school choice in the public sphere and academic literature but put those considerations aside - at the risk of not raising questions about how this may contribute to resegregation of already marginalized communities. Instead, Brinig and Garnett move on to argue for school choice as a way to advocate for the continued existence of Catholic schools in urban neighborhoods. For the authors, school choice allows Catholic schools not only to exist but also to contribute to the neighborhoods where they are needed most — urban communities most affected by high rates of poverty. Brinig and Garnett support the right of charters to exist but would rather that Catholic schools remain private schools and argue against Catholic charter schools. They see the latter as secular versions of traditional Catholic schools and, as a result, less effective.

In the last chapter, Brinig and Garnett make a final plea for keeping Catholic schools in the urban landscape. They are sober about the fact that Catholic schools are different from public schools. Catholic schools do not accept all children, parents select Catholic schools (selection bias), and Catholic schools can ask students to leave. However, Brinig and Garnett maintain that the data are

\section{4 American Journal of Education}


on the side of Catholic schools. These schools make considerable contributions to the neighborhoods in which they are members and thus should remain in them.

As a historian of Catholic education and a teacher educator who works regularly with urban Catholic and public schools, I found Lost Classroom, Lost Community an important contribution to the literature on Catholic schools and on urban education. I believe the approach to examining Catholic schools as community institutions is critically important and well overdue in the literature examining contemporary contributions of Catholic schools.

I am skeptical of the findings on charter schools because Catholic schools in Chicago have a long and storied past with a large well-established institution supporting them. Charter schools are much newer to the educational milieu and more transient in terms of their shelf life compared with both traditional public schools and Catholic schools. I believe it will take some time before reliable results can be generated from the hypotheses that Brinig and Garnett have proposed about and applied to charter schools.

The arguments that Brinig and Garnett have offered about school choice are certainly novel and well grounded in the conclusions of their research. As noted earlier, their call for increasing choice has clearly been heard-if not directly, then indirectly (US Conference of Catholic Bishops, 2018). That said, the central characters of Lost Classroom, Lost Community, the schools of the Archdiocese of Chicago, have seen some 25 schools closed or reconfigured since 2014. Illinois, however, just passed its own tax credit scholarship legislation in 2017, and this coming school year, 2018-19, the state will implement a program targeting lowincome students wishing to attend private schools, including Catholic schools. The school choice debate continues to shift radically and swiftly. I concur that Catholic schools need to remain a vital part of the urban educational environment, but the question remains whether the direction of school choice policy will better serve all students.

\section{References}

Bryk, Anthony S., Valerie E. Lee, and Peter B. Holland. 1993. Catholic Schools and the Common Good. Boston: Harvard University Press.

Campbell, David E. 2008. "The Civic Side of School Choice: An Empirical Analysis of Civic Education in Public and Private Schools." BrU Law Review 2008 (2): 487-523.

Coleman, James S. 1988. "Social Capital in the Creation of Human Capital." American 7oumal of Sociology 94:S95-S120.

EdChoice. 2018 "Resource Hub: Fast Facts." https://www.edchoice.org/resource -hub/fast-facts/.

National Conference of State Legislatures. 2017. "Interactive Guide to School Choice Laws: Public and Private School Choice." http://www.ncsl.org/research/education /interactive-guide-to-school-choice.aspx. 
Putnam, Robert. 2000. Bowling Alone: The Collapse and Revival of American Communitv. New York: Simon \& Schuster.

US Conference of Catholic Bishops. 2018. "Catholic School Research and Studies." http://www.usccb.org/beliefs-and-teachings/how-we-teach/catholic-education /k-12/upload/Catholic-Schools-FACT-Sheet-Handout.docx.

Wolf, Patrick J. 2007. "Civics Exam." Education Next 7 (3): 66-72.

\section{American Journal of Education}

